\title{
特集「LCA によせる期待」
}

\section{解 説 \\ 意思決定支援ツールとしてのLCAの応用例 ～調查研究事例紹介〜}

緒方 順一

\section{Application of LCA as a evaluation tool for decision making. Introduction of the case studies.} Junichi OGATA

\begin{abstract}
Synopsis: In this paper, proposed was a new evaluating indicator, a kind of sustainable indicator, using LCIA together with economical and beneficial evaluation simultaneously. First, surveyed were existing evaluation methodologies like "Eco-Efficiency" by WBCSD, etc. Then a new evaluation indicator was proposed and applied to recycling issues of specific waste plastics and public sewage treatment process. Our indicator is unique, in which three aspects, i.e. Benefit, Ecology and Economy are considered together. This study will give an helpful information to the people who are thinking of application of LCIA
\end{abstract}

Key words: Eco-efficiency, Environmental Performance Evaluation, Recycle, Sweage Treatment, Waste Plastics

はじめに

筆者は、ここ 10 年ほど鉄鋼製品や各種環境プラントの LCA分析にかかわってきた。またLCA フォーラムやそれ に続くLCA プロジェクトに参加させていただいている。 10年程前にLCA フォーラムで議論を始めた頃に比べると、 世の中への広がりという点で大きく進展した感がある。し かしながら、LCAの手法としての課題も依然残されてい る。たとえば、バックグラウンドデータとしてのインベン トリーデータのさらなる充実、また環境影響統合化指標を 含むインパクト評価手法の確立などが望まれる。さらに、 LCAの結果をどのように使えるかについてはまだあまり 検討されていないように感じる。LCAは、対象の製品や サービスの環境影響という側面を評価する手法であり、す べての局面においてインパクト評価の結果が最小になるよ うに配慮すべきであると言われる。原則はこのとおりであ るが、現実世界における意思決定は、得られる便益・効用 およびそのために必要なコストとの対比において決定され るのが常である。したがって、LCAの結果を意思決定の ための支援ツールとして利用するためには、これらすべて の要素を同時に考虑することが必要であると考える。現 在、このような考え方の例として、環境影響を便益・効用 との対比で測るという「環境効率」の評価が進みつつある。 すなわち、環境効率 $=$ 便益・効用 $/$ 環境影響という計算式 で評価する考え方である。また、環境影響をコスト (経済 性)との対比において評価する手法も出てきている。

筆者はある研究グループ脚注1) において、リサイクルの
効用(得失)を総合的に評価し、そのあり方について研究を 行う活動に参加した。本研究においては、環境効率の考え 方をべースとしつつ、これに経済性も同時に考慮した評価 手法の開発を試みたものである。具体的対象として容り 法・廃プラスチックのリサイクルおよび下水処理を事例と してとり上げ、便益・効用と経済性に関する評価も同時に 考慮した新しい評価指標を策定した。本研究においては、 インパクト評価としては産業技術総合研究所が開発した被 害算定型統合化係数LIME (Life cycle Impact assessment Method based on Endpoint modeling) を使用し、効用と 経済性に関する評価も同時に考慮した新しい“3 軸評価”を 試みた。この結果、リサイクルのあり方に関して有意義な 示唆を得ることができた。また、評価手法としての課題も 明らかになった。本研究で提案した評価手法はこれまでに ない新しい手法であり、LCAの応用例としても有意義で あると思われるので、以下、本紙面を借りて研究の内容を ご紹介する。

\section{1. 調査研究の背景と目的}

循環型社会の実現を目指して $3 \mathrm{R}$ を促進する政策が進め られており、産業界においてもこれに対応して様々な技術 開発が進められている。しかし、一方では経済的な理由な どによってなかなか進まない現実がある。 $3 \mathrm{R}$ のうちリデ

注 1 社団法人 日本产業機械工業会 平成 15 年度 リサイクルの評価技術調查研究委員会 - 廃懍物処理およ び下水処理における新環境評価手法の提案委員長 (早稲田大学理工学部教授 大和田秀二) 
ユース (Reduce)、リユース (Reuse)に関してはほとんどの 場合、無条件に環境影響の低減につながると考えられる。 しかしリサイクルに関しては、何をどこまでリサイクルす べきなのかということに関して明暸な判断基準はできてい ない。環境影響の側面だけに限って考えると、リサイクル プロセスによって新たに発生する環境影響が、リサイクル を行わない場合よりも小さい範囲でリサイクルを推進す心゙ きであるということができる。しかしこの評価を行うため には異なる環境影響カテゴリーの環境影響を合計してその 大小を比較するということが必要になる。このための評価 ツールとしてはLCAにおけるインパクト評価統合化係数 を使う必要が生じる。

つぎに、リサイクルの判断基準としては、環境側面だ けでなくリサイクルによるさまざまな便益とコスト（経済 性)についても併せて評価する必要がある。この場合の便 益は、広義の環境負荷を低減するということだけでなく、 新たな市場価值の創出や人間の生活面に及ぼす効果につい ても考慮すべきであろう。このような便益は、個別のリサ イクル技術によってそれぞれ異なった形で現れるので、対 象別に評価する必要がある。また経済性については現実の 社会で最も大きな要因であり、リサイクル技術の評価を行 う上では必ず考慮しなければならないものである。

以上、リサイクルを評価する上で重要と思われる要因に ついて述べたが、本調査研究では、評価の 3 要素として環 境、便益・効用、経済性のすべてを同時に考慮した新しい 評価手法の開発を試みたものである。具体的には、事例と して廃裹物処理分野における容リ法廃プラのリサイクルお よび下水処理分野における污泥リサイクル等を採り上げ、 新しい評価手法の作成を行った。またこの評価手法は廃裹 物処理事業や下水処理事業全体の評価を妨げるものではな く、同様な評価を行うことができる。

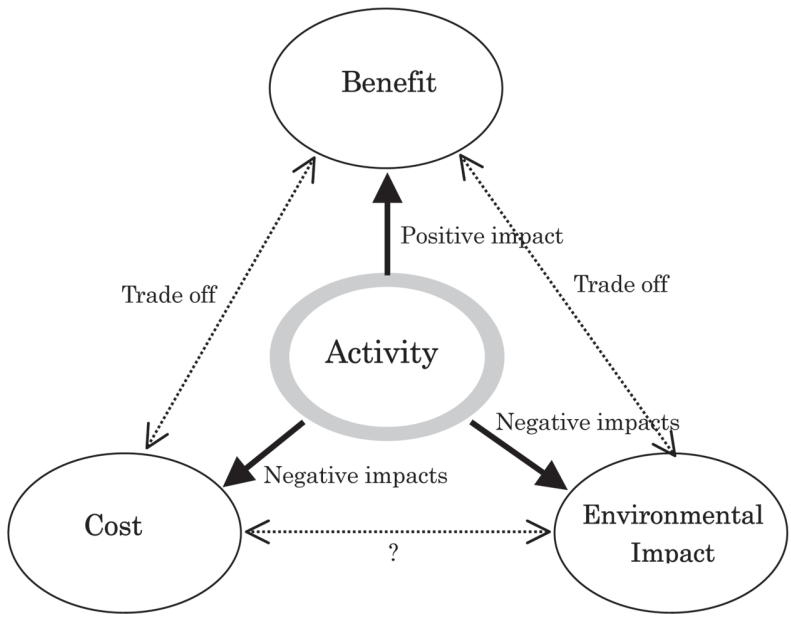

Figure.1 Three aspects of total evaluation on objective activity

\section{2. これまでの環境評価手法の調査}

本調査研究委員会においては、評価の 3 要素である経済 性、便益、環境のすべてを同時に考慮した新しい評価手法 の開発を目指したものであるが、それに先立ち、これまで 国内外でどのような評価手法が開発されてきたかについて 調査を行った。以下、各評価手法の概要を述べる。

(1) WBCSD:「エコ・エフィシェンシー」1)

1992年、経済成長と生活の質を向上させることを企図 して、「エコ・エフィシェンシー」という考え方を、具体的 な指標の作り方を含めて発表した。Eco-efficiencyの“eco” は、経済性 (economical) と環境 (ecological)を表している。 ここでは、指標を「一般的に適用可能な指標」と「事業特有 の指標」に分類している。「一般的に適用可能な指標」は、 グローバルな環境問題に関連する指標であらゆる事業に適 用可能である。一方、「事業特定的な指標」は、ある事業、 ある産業ごとに個々に選択される指標で、事業内容や産業 の性質に依存する指標である。このどちらを使うこともで きるとしている。

エコ・エフィシェンシーの算式は、 エコ・エフィシェンシー＝製品・サービスの価值／環境影響 価值の要素は、製品・サービス価值カテゴリーにおける一 般的に適用可能な指標か事業特有の指標のいずれかで、環 境影響の要素は製品・サービスの創造と使用による環境影 響カテゴリーに属する指標で構成される。したがって、計 算されるエコ・エフィシェンシー指標の可能性はたくさん あり、どのような計算を行うかは、個々の意思決定者の二 ーズに任される。

この評価手法の特徵は、対象範囲が広く、また評価者の 目的に応じてさまざまな指標を作ることができるという特 徴がある。現在わが国の民間企業で導入している環境効率 はほぼこの考え方に則った指標を作成しているところが多 い。このように、本手法は目的に応じて便利に使える反面、 すべての対象に対して統一的な指標とすることには難点が あると思われる。

(2) 環境省「環境パフォーマンス指標」2)

目的としては、環境への取組に係る事業者内部における 評価・意思決定に資する情報を提供し、外部の利害関係者 の理解を助けるために共通の情報基盤を提供すること、さ らに、国、地方公共団体などの環境政策と、事業者の環境 活動を整合させていくための共通の情報基盤を提供するこ とである。

環境パフォーマンス指標は以下の 3 つに分類される。 (1)オペレーション指標、(2)環境マネジメント指標、(3)経営 関連指標。さらに、オペレーション指標の一部はコア指標 
(重要指標)として定義されている。その他の指標はサブ指 標として、事業者が必要に応じて選択するものとなってい る。

\section{実際の指標は :}

単位環境負荷当たりの製品・サービス価値

$=$ 経営指標等 $/$ 環境負荷総量

単位製品・サービス価值当たりの環境負荷

$=$ 環境負荷総量 $/$ 経営指標等

の二つのケースが定義されている。

異なる環境負荷指標を統合した指標、LCA的アプロー チによる指標の開発、環境効率性を表す指標の開発につい て言及しているが、これはその必要性と、同時に難しさが あることも暗に示したものと思われる。今後の課題とし て、個別の企業に適合したものだけではなく、共通の指標 として算定可能な環境効率性を表す指標の開発をさらに進 めていく必要があるとしている。

(3) クリーン・ジャパン・センター「製品アセスメント」 ${ }^{3)}$

製品の 3 R配慮設計を効率的に進めていくために、製品 の環境 (3R) 性を評価し、問題点を抽出し、重大なものか ら優先的に経営資源を注いで対策していくといった一連の 作業を行うための事前評価マニュアルとして作られてい る。この手法の特徵的なことは、評価項目と評価方法が非 常にわかりやすく整理されていることである。たとえば 3 R共通項目として、部品点数の大小で評価するなど、通常 のチェックリストのように評価を行えるようになってい る。環境への影響を議論する場合、通常はLCA手法によ ってそれが及ぼす影響を仔細に調查することが求められる が、この場合、「部品点数が少ないことは良いこと」という ように決められており、このような具体的な評価項目を積 み重ねることによって、全体の評価を行うものである。

(4) APME (Association Of Plastics Manufacturers in Europe、欧州プラスチック協会)：“Eco-efficiency” 4)

BASF社が行った手法を使って、廃プラリサイクルの評 価を行っている。ここでは、環境影響と経済性の二つの要 素を、二軸平面上にプロットすることで、特性の分析を行 うことができる。この二つの要素で考えるかぎりは非常に 分かりやすい評価方法である。ただし、この結果を一つの 数值で表現することはできない。

(5) プラスチック処理促進協会「エコマップ」5)

APMEと類似した考え方で容リ法廃プラのリサイクル シナリオの評価を行っている。結果は「エコマップ」とし て、やはり環境影響と経済性の二つの要素を、二軸平面上 にプロットし評価する方法をとっている。
(6) 国内民間企業 :「環境効率」6)

産業環境管理協会の調査によると、現在国内企業で、環 境効率を取り入れている企業数は 20 程度と思われる。環 境効率の定義 (=効用 / 環境影響)のうち効用 (分子)、環境 影響 (分母)の定義はさまざまであり、対象としても単独製 品の場合と事業全体の場合がある。事業活動全体を評価し た場合は、便益・効用として売上 (金額または物量)を使用 している。個別製品を対象とした場合の便益・効用は、製 品の代表的な性能を使っている例が多い。環境影響項目と しては、業種によってあるいは会社ごとに違いが見られ る。温暖化については共通してとり上げているが、その 他の項目 (資源消費、大気排出、排水項目、廃棄物など) についてはさまざまである。また、いくつかの環境影響項 目を挙げている場合はそれぞれの項目ごとに環境効率を計 算しており、すべての環境影響を統合化することは行われ ていない。例は少ないが、 5 項目の環境影響項目の影響を CVM手法 (Contingent Valuation Method)によって金額 表示し、これを統合化している企業もある。

以上のように、全体として、非常に分かりやすい形で環 境効率の改善度合いを表現するという意図が感じられる。 しかしながら、便益・効用の評価において非常に単純化し ているため、実製品の多様な性能を表わしているとは言い がたい面がある。自社製品あるいは事業の改善度合いを相 対的に測るものさしとして使用されていると言える。

(7) 日本下水道協会「費用便益分析」7)

下水道や社会資本整備に関して透明性および客観性の確 保、効率性の一層の向上を図ることを目的として、下水道 事業の費用効果分析を行っている。下水道事業の費用 ( C ) と便益 (B) を個別に算定し (ともに金額単位)、両者の比 (B / C ) を費用便益比として評価している。また両者の差 分 $(\mathrm{B}-\mathrm{C})$ を純便益として計算している。

便益の算出方法として、興味深い考え方が示されてい る。すなわち、便益の内容として下記の 5 項目に区分して 算出することを提案している。(1)生活環境の改善効果、(2) 便所の水洗化効果、(3)公共用水域の水質保全効果、(4)浸水 の防除効果、(5)その他の効果

しかし、各項目の算定方法に関しては、代替工法の費用 を算定してこれを便益として計算するなど、まだ手法とし ての改善余地があると思われる。公共用水域の水質保全効 果による環境価値の保全に関してはCVM法による方法を とっている。また、ここでは環境インパクトの要素は考虑 されていない。以上より、個々の項目の定量化方法には改 良の余地があると考えられる。

\section{3. 新評価手法の概要}




\section{1 評価の 3 要素}

ある対象 (Activity) に関する三つの評価要素 (便益・効 用“B”、環境影響“L”、コスト “C”) を考虑する。この上で、 評価指標作成の原則として、下記の二点を設定した。

1 ）評価指標は上記三つの要素を同時に考慮したものとす る。すなわち、得られる便益に対してコスト（内部コ スト) と環境影響 (外部コスト)の合計を総コストと考 え、総コストに対する便益の大きさを評価する指標と する。

2 ）評価は絶対評価を行うことを目指した。すなわち、同 一目的の複数のプロセス (選択肢)の優劣を相対的に比 較するだけでなく、単独で絶対評価を行うことを目指 す。すなわちある事業が、発生するコストや環境負荷 と対比して有益であるかどうか、またどの程度有益で あるかについて定量的な評価を行うことを目指す。

本研究では事例として下記の 2 ケースを取り上げ、上記 の考え方にしたがって評価指標を作成した。そのための各 要素の算定方法は以下のとおりである。

事例 1 : 廃裹物処理分野における容り法・その他プラのリ サイクル (マテリアルリサイクル、サーマルリサ イクル、ケミカルリサイクル)

事例 2 : 污泥リサイクル、消化ガス発電等を含む下水処理 事業

\section{（1）コスト(経済性)}

対象の活動を行うために必要な総費用をコストとして算 定する。本来このコストには設備建設費、人件費などすべ てを含める。ここで計上するコストは、環境会計で言うと ころのいわゆる「内部コスト」である。ただし本研究におい ては、設備コストについてはデータが十分ではないため、 運転費、維持管理費、人件費を計上した。単位は金額表示。

\section{(2) 環境影響(インパクト評価)}

対象の活動に起因する環境影響をLCA 手法によって算 定する。すなわち、評価目的に応じてシステム境界を設定 し、その中でのインベントリー調査を行い、環境影響評価 を行う。環境影響評価は、様々な環境影響カテゴリーのイ ンパクトを、最終的に単一指標(統合化係数)に集約して使 用する。単一指標 (統合化係数)に関してはまだ研究開発の 段階ではあるが、本調查研究の目的に対しては被害算定型 統合化係数LIMEを使用した。LIMEではインパクトの定 量化単位として無次元数、およびコンジョイント法を併用 することによって金額表示している。本調査研究において は金額表示の統合化係数を使用した。金額で表示された環 境影響は、環境会計で言うところのいわゆる「外部コスト」
として扱うことができる。なお、環境影響として無次元単 位の表示を使用することも可能であるが、その場合、三つ の評価要素を組み合わせて指標化する際に制約を受ける。 たとえば内部コストと外部コストの合計を総コストとする とき、外部コスト (環境影響)が無次元単位であると両者の 和をとることができない。この他にも、指標化する際には、 三つの要素がすべて金額単位であれば、指標化が容易であ り、作成された指標の理解も簡単である。以上より、本研 究においてはすべて金額で表示できる手法を採用した。

(3) 便益・効用

ある活動の便益・効用は様々な形で顕われる。まずその 活動の本来の目的を達成した場合の物理的効用が挙げられ る。たとえば廃棄物処理におけるリサイクルを評価する場 合、便益・効用としては、資源消費の低減効果、再生品に よってバージン製品の生産量を低減する効果、および最終 処分量を低減する効果等があげられる。これらの効用は、 本研究においては「目的効用」として整理する。つぎに経済 的側面では、再生品の市場価值が発生する。本研究におい ては「市場価值」として整理する。以上はダイレクトに定量 化が可能な効用であるが、このほかに、重要な効用として、 無形の便益・効用が挙げられる。たとえば下水処理事業に おいては、この無形の効用を事業の効用として次のように 整理している7)。本研究においてはこれら無形の効用を「社 会的効用」として整理した。

下水処理事業における無形の効用

1 便所の水洗化

2 周辺環境改善

3 公共用水域の水質保全

4 下水道の多目的利用

5 浸水の防除

これらの効用は下水処理事業の本来の目的であり、事業 全体の絶対評価を行う場合にはこの効用を無視することは できない。しかし、この「社会的効用」を定量的に評価する ことは簡単ではない。現在、環境経済学の分野においてコ ンジョイント法、CVM法などによって効用を金銭価值で 算定する研究が盛んに行われている。本委員会において は、CVM法による過去の測定結果を使った。

以上、ある活動によって得られる効用として (1)目的効 用、(2)市場価值、(3)社会的効用の三項目を金額単位で算定 し、これらを合計して効用 B として評価した。すなわち、 効用 $\mathrm{B}=($ 目的効用 + 市場価值 + 社会的効用 $)$ ここで注意すべき点は、三つの効用を合計して良いかどう かということである。これらはすべて一つの活動から得ら れる効用を様々な側面から評価したものである。したがっ て単純に合計すると効用のダブルカウントにならないかと 
いうことを考える必要がある。特にLIMEのように、環境 影響を金額表示の統合化係数で表わす場合には、次の点に 注意を払う必要がある。たとえばLIMEにおいては排水項 目 COD (Chemical Oxygen Demand) は湖沼の富栄養化に 寄与し、社会資産の減少につながるとしている。そしてこ れに対するWTP (Willingness To Pay)を測定して、これ からCODの環境影響統合化係数を金額表示で求めている。 本研究ではこれを下水処理事業における「目的効用」として
算定しているが、同じ内容の効用が、「社会的効用」の中に も含まれているとダブルカウントになってしまう。したが って、目的効用、社会的効用を算定する場合は、このよう なチェックを行うことが必要である。本研究の場合は、社 会的効用としては「公共用水域の水質保全」に対するWTP を使用したが、COD減少という目的効用とは別のものと 解釈して、それぞれ算定した。この点についてはまだ議論 の余地がある。

Table1 Calculation methodology for each of 3 aspects of total evaluation on designated waste plastics recycling

\begin{tabular}{|c|c|c|c|}
\hline 3 aspects & Classification & Corresponding processes & Calculation methodology \\
\hline \multirow{4}{*}{$\begin{array}{l}\text { Benefit } \\
\text { (B ) }\end{array}$} & \multirow[t]{2}{*}{ Objective performance } & \multicolumn{2}{|c|}{$\begin{array}{l}\text { In case of MR } \\
\text { recycled one. } \\
\text { In case of TR: Avoided environmental impact which would be caused by production of virgin material equivalent to } \\
\text { not recovered at incineration. } \\
\text { In case of CR: Avoided environmental impact which would be caused by coal utilization at steel works when } \\
\text { recovered plastic was not utilized at steel works }\end{array}$} \\
\hline & & Reduction of environmental impact by decreasing landfill & Calculated by LIME \\
\hline & Economical benefit & Economical benefit gained by selling the recycled products & $\begin{array}{l}\text { MR: selling price of recovered plastic } \\
\text { TR: selling price of electric power recovered at } \\
\text { incineration } \\
\text { CR: purchase price of coal }\end{array}$ \\
\hline & $\begin{array}{l}\text { Benefit of social and living } \\
\text { quality improvement }\end{array}$ & Domestic waste collecting service & Measurement by CVM methodology \\
\hline \multirow{4}{*}{\multicolumn{2}{|c|}{$\begin{array}{l}\text { Environmental Impact } \\
\text { ( L ) }\end{array}$}} & Waste collection service & Consumption of diesel oil \\
\hline & & Recycling process & $\begin{array}{l}\text { MR,CR: Environmental impact caused by recycling } \\
\text { processes. } \\
\underline{\text { TR: Environmental impact caused by incineration. }}\end{array}$ \\
\hline & & Landfill & Calculated by LIME \\
\hline & & Resource consumption & Calculated by LIME \\
\hline \multirow{4}{*}{\multicolumn{2}{|c|}{$\begin{array}{l}\text { Cost } \\
\text { ( C ) }\end{array}$}} & Waste collection and transport & Data from the study on K-city \\
\hline & & Recycling process cost for MR and CR & Assumed as bid price \\
\hline & & Incineration and power recovering cost for TR & Referred to the data of $\mathrm{PWMI}^{* 4}$ \\
\hline & & Landfill cost & Referred to the data of PWMI ${ }^{* 4}$ \\
\hline
\end{tabular}

*3 MR: material recycling, TR: Thermal Recycling, CR: Chemical Recycling

*4 Plastic Waste Management Institute

Table2 Calculation methodology for each of 3 aspects of total evaluation on sewage treatment system including sludge recycling

\begin{tabular}{|c|c|c|c|}
\hline 3 aspects & Classification & Corresponding processes & Calculation methodology \\
\hline \multirow{9}{*}{$\begin{array}{l}\text { Benefit } \\
\text { ( B ) }\end{array}$} & \multirow{6}{*}{ Objective performance } & Improvement of water quality (BOD,COD,SS,T-N,T-P) & Calculated by LIME \\
\hline & & Reuse of treated water & $\mathrm{CO}_{2}$ emission reduction by using treated water \\
\hline & & Recovery of digestion gas for electricity generation & Reduction of grid power consumption \\
\hline & & Recovery of digestion gas for thermal utilization & Reduction of heavy fuel oil consumption \\
\hline & & $\begin{array}{l}\text { Effective use of ash from sludge incineration (brick, cement, } \\
\text { soil improvement) }\end{array}$ & Reduction of virgin material production \\
\hline & & Reduction of landfill & Reduction of environmental impact caused by landfill \\
\hline & \multirow{2}{*}{ Economical benefit } & $\begin{array}{l}\text { Recovery of digestion gas for electricity generation and } \\
\text { thermal utilization }\end{array}$ & $\begin{array}{l}\text { Income by selling electricity. } \\
\text { Reduction of heavy fuel cost }\end{array}$ \\
\hline & & $\begin{array}{l}\text { Effective use of ash from sludge incineration (brick, cement, } \\
\text { soil improvement) }\end{array}$ & Income by selling recycled products \\
\hline & $\begin{array}{l}\text { Benefit of social and living } \\
\text { quality improvement }\end{array}$ & Conservation of sound river/sea & Measurement by CVM methodology \\
\hline \multicolumn{2}{|r|}{$\begin{array}{l}\text { Environmental Impact } \\
\qquad(\mathrm{L})\end{array}$} & $\begin{array}{l}\text { sewage treatment system including recycling processes } \\
\text { (digesting gas, sludge, etc) }\end{array}$ & $\begin{array}{l}\text { Directory referred to the data disclosed by municipal } \\
\text { facility. }\end{array}$ \\
\hline & $\begin{array}{l}\text { Cost } \\
(\mathrm{C})\end{array}$ & $\begin{array}{l}\text { Operational cost of the treatment system including recycling } \\
\text { processes. }\end{array}$ & $\begin{array}{l}\text { Construction costs for facilities were not considered } \\
\text { due to lack of data. }\end{array}$ \\
\hline
\end{tabular}




\section{2 個別要素の試算例}

本研究では上記の二つの事例に対して、以上のべた 3 要 素の算定方式に従い、Table 1、Table 2に示す内容を計上 した。

\section{3 新しい環境経済評価指標の作成}

以上の手順で、評価の三要素 (便益・効用 B、コスト $\mathrm{C}$ 、 環境影響L)を金額単位で表わし、つぎにこれらを使って 評価指標を作成する。

評価指標は、対象の活動によって得られる効用 Bと、こ のトレードオフとして発生する環境影響LおよびコストC を対比させる形で作成することとした。これによって経済 学で言うところの費用便益分析の考え方、

$$
\text { 正味便益 }=\text { 便益 }- \text { コスト }
$$

に則った形で正味の便益を評価することができる。ただ し、この場合の便益は経済的な便益だけでなく、先述のと おり “拡大された便益”であり、コストについても経済的コ ストだけでなく外部コスト(環境損失)も含む“総コスト”を 表わすことになる。以上より、この場合の評価指標は、

正味便益 $=$ 拡大便益 - 総コスト

ということになる。これで計算される正味便益は環境効用 (物理的効用) と経済的効用の両方を加味したものとなるの で、「環境経済正味便益」と呼ぶことにする。これを式で表 わすと、

環境経済正味便益 $=\mathrm{B}-(\mathrm{L}+\mathrm{C})$ 単位 : 金額 つぎに、拡大便益 $\mathrm{B}$ と総コスト $(\mathrm{L}+\mathrm{C})$ の差をとるのではな く比率で表わすこともできる。この場合、環境効用 (物理 的効用）と経済的効用の両方を加味した効率を表わすもの であるから「環境経済効率」と呼ぶことにする。

環境経済効率 $=\mathrm{B} /(\mathrm{L}+\mathrm{C})$ 単位 : 無次元 つぎに、二つの要素の対比として B / LあるいはB $/ \mathrm{C}$ も重要な意味を持っている。前者 $\mathrm{B} / \mathrm{L}$ はすでに使われて いるいわゆる「環境効率」であり、後者は「経済効率」という ことができる。これらの指標は評価対象の特性を表現する 指標として有効である。

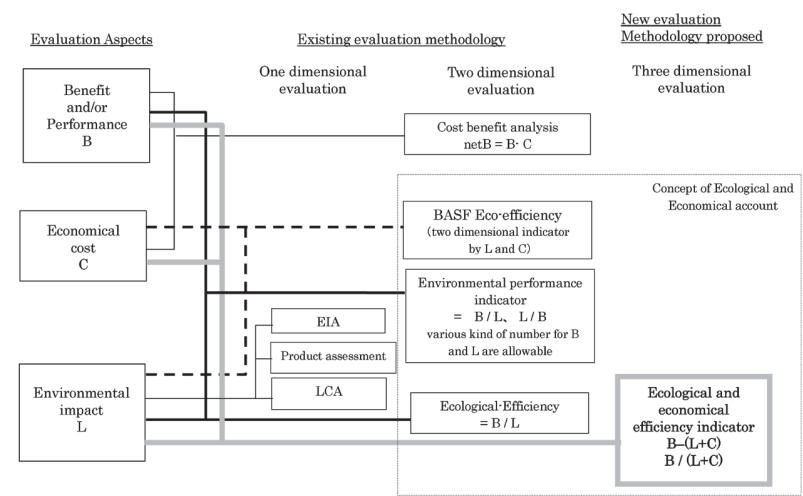

Figure. 2 Progress of evaluation methodology and the new methodology proposed here.

$$
\begin{array}{ll}
\text { 環境効率 }=\mathrm{B} / \mathrm{L} & \text { 単位: 無次元 } \\
\text { 経済効率 }=\mathrm{B} / \mathrm{C} & \text { 単位 : 無次元 }
\end{array}
$$

本研究では、以上四つの指標を作成した。従来の評価指標 との関連を Figure. 2 に示した。今回作成した評価指標は、 広義の環境会計の一つの手法ということが出来る。最大の 特徴は、「三軸評価」と記したように、評価の三要素を同時 に加味して評価する手法という点である。

\section{4. 評価試算結果}

先述の二つの事例についてTable 1、Table 2に示した 内容で三つの評価要素 $(\mathrm{B}, \mathrm{L}, \mathrm{C})$ の計算を行い、これを使っ て評価指標の計算を行った。この結果を以下に示す。 事例 1 ：容リ法・その他プラのリサイクル $(\mathrm{MR}, \mathrm{TR}, \mathrm{CR})$ 事例 2 : 污泥リサイクル、消化ガス発電等を含む下水処理 事業

事例 1 では、廃プラリサイクルの手段による違いを評価 した。ここで示した結果は一例であり、実際の研究では、 不確定な元デー夕についてはパラメトリックに変化させて 複数のケースについて評価した。したがって、ここで示し た評価結果は、リサイクル手段の評価に関する結論ではな いことに注意されたい。Figure. 3において、各リサイク ル手段による相対的な差が表れている。しかし本評価は絶 対的な評価を行うことができるものであり、環境経済効率 が 1 以上であるかどうか、すなわち総コストに対して総便 益がそれ以上であるかどうかが見られるようになってい

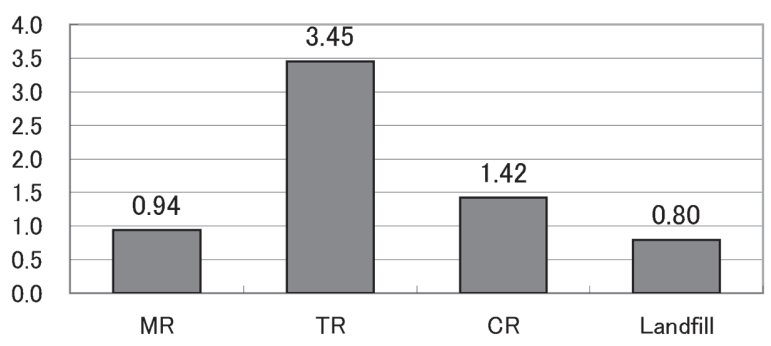

Figure.3 Result of evaluation by new indicator of "Ecological-Economical Efficiency" on designated waste plastic recycle: $B /(L+C)$

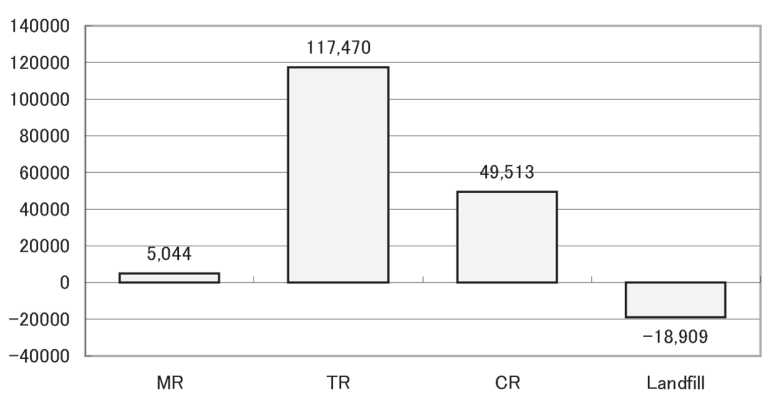

Figure. 4 Result of evaluation by new new indicator of "EcologicalEconomical net benefit" on designated waste plastic recycling: B $-(L+C)$ yen per tonne of plastics $)$ 


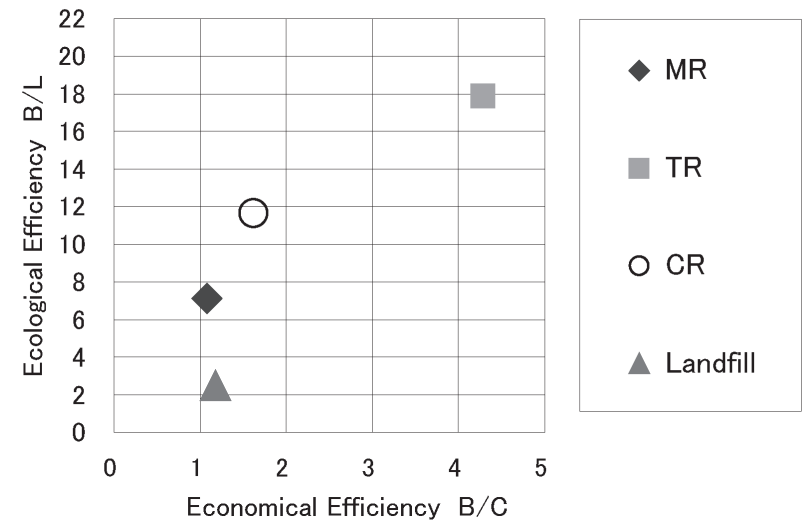

Figure.5 Analysis by using "Ecological efficiency and Economical efficiency" on designated waste plastic recycling

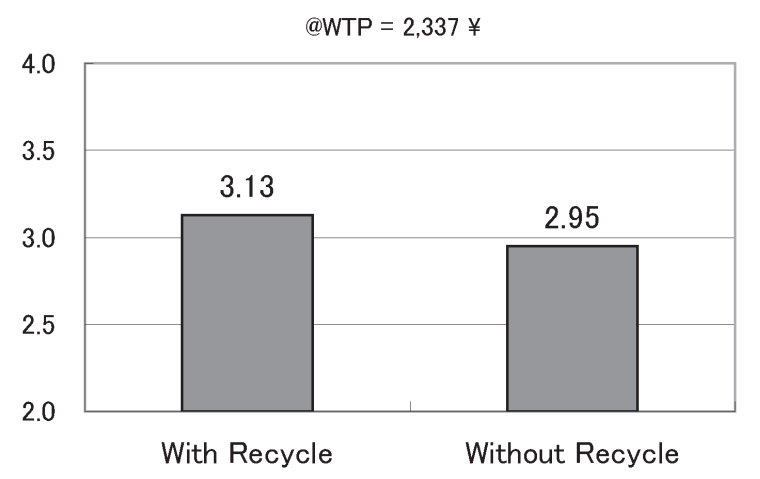

Figure.6 Result of evaluation by new indicator of "EcologicalEconomical Efficiency" on sewage treatment system of city X: B / $(\mathrm{L}+\mathrm{C})$

る。同様に、Figure.4においては環境経済正味便益がゼ ロ以上であるかどうかを判断できるようになっている。 Figure. 5 は環境効率、経済効率を縦軸と横軸にとり整理 したもので、各リサイクル手段の特徵が良く現れている。

事例 2 では、下水道事業において污泥リサイクル、消化 ガス発電等を実施する場合、しない場合の比較を行った。 結果を Figure. 6 ～Figure. 8に示す。図の見方については 同様である。

\section{まとめ}

以上、LCAの結果を総合的な意思決定ツールとして使 うための新たな評価指標の作成について、研究事例を紹介 した。本研究ではLCAによるインパクト評価結果だけで なく、経済性および便益・効用についても一定のルールで 算定し、対象事業の「価值」を絶対評価することを試みたも のである。一般的に、大規模の公共事業はその存在価值が 無形の価值としてしか表現しにくいものが多い。たとえば 下水道事業によって維持される衛生的で且つ自然と調和し た生活環境の実現は非常に大きな価值を持っているが、そ れを定量的に表現する方法がまだ定まっていない。本研究 においては、CVM法等による算定結果などを利用したが、 この方法に対する議論が残っていることも事実である。本

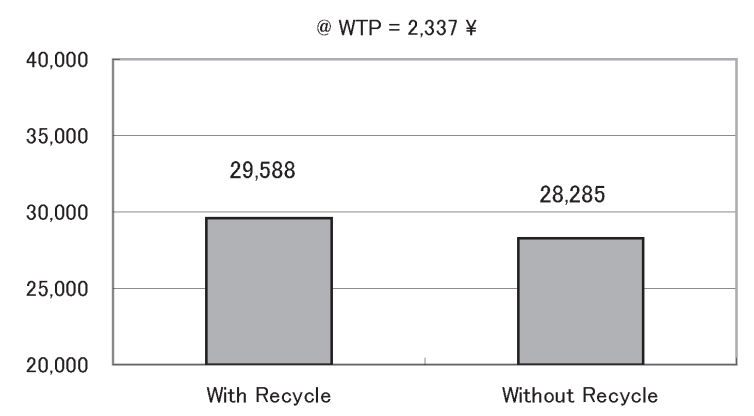

Figure. 7 Result of evaluation by new indicator of "EcologicalEconomical net benefit" on sewage treatment system of city $\mathrm{X}$ : B $(L+C)$ million yen per year

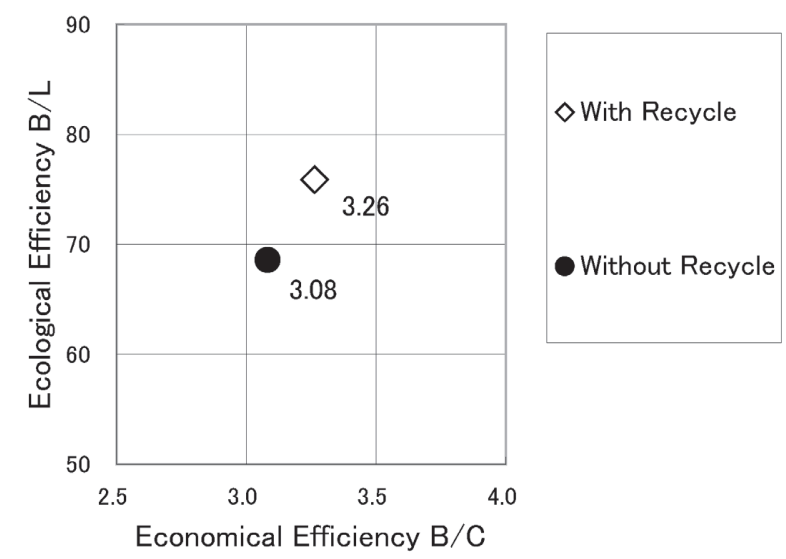

Figure. 8 Analysis by using "Ecological efficiency and Economical efficiency" on sewage treatment system

研究を行ったグループ内部においても賛否が相半ばしてい る状況である。一方、産業技術総合研究所が開発したイン パクト評価LIMEにおいてはコンジョイント法という方法 によって、環境影響を金銭価值に換算することが行われて おり、本研究はこの結果を利用したものである。このよう に、LCAの結果を、より大きな枠組みの中での評価に利 用するときにはCVM法やコンジョイント法なども活用し ていく必要があると考えられる。

LCA は物事の環境側面を評価する手法であり、その点 では異論を挟む余地はない。しかし現実の諸々の問題を考 える際には、それによって得られる便益・効用や必要なコ ストを抜きにしては有効な決定は下せない。したがって、 LCAがそれだけにとどまっていては逆にLCAの結果が考 慮されない結果になりやすいと考える。筆者は、産業界に 身をおく立場で考えるとき、LCAの結果をコストや便益・ 効用と同時に考慮したうえで使用できるように、新たな評 価手法が必要だと考える。現在進みつつある「環境効率」の 評価はこのための第一歩であり、これをさらに進めて経済 性に関しても同時に考慮できる評価手法を開発すべきであ ると考える。このために、本誌で紹介した研究が一助とな れば幸いである。 


\section{引用文献}

1）経済産業産業技術環境局環境政策課：“環境管理会計手 法ワークブック”, 社団法人産業環境管理協会 (2002) p268

2）環境省総合環境政策局環境経済課：“事業者の環境パフ オーマンス指標ガイドライン -2002 年度版 - ,

http://www.env.go.jp/policy/report/h15-01/index.html, (2003), p63

3）財団法人クリーン・ジャパン・センター：“製品アセス メント一般指導書作成作業報告書（3Rに配虑した製品 の評価・設計の方法)”, (2003), p152

4) TNO: "TNO-MEP-R2000/119 Eco-efficiency of recovery scenarios of plastic packaging, http://www.apme.org/dashboard/business_layer/ template.asp?url=http://www.apme.org/media/ public_documents/20010822_112137/literatuur_ technical_39.htm\&title=Eco-efficiency+of+ recovery + scenarios + of +plastic+packaging,$+(2001)$, p139

5）社団法人プラスッチク処理促進協会：“廃プラスチック 処理・処分システムのエコ効率分析”, (2003), p77

6）社団法人産業環境管理協会: “平成 14 年度経済産業省 委託 環境調和型事業活動導入促進調查 (環境効率)”, (2003), p216

7）社団法人日本下水道協会：“下水道事業における費用効 果分析マニュアル (案)”, (1998), p133 